(c) American Dairy Science Association, 2005.

\title{
Genetic Improvement in Mastitis Resistance: Comparison of Selection Criteria from Cross-Sectional and Random Regression Sire Models for Somatic Cell Score
}

\author{
J. Ødegård, G. Klemetsdal, and B. Heringstad \\ Department of Animal and Aquacultural Sciences, \\ Norwegian University of Life Sciences, PO Box 5003, N-1432 Ås, Norway
}

\section{ABSTRACT}

Several selection criteria for reducing incidence of mastitis were developed from a random regression sire model for test-day somatic cell score (SCS). For comparison, sire transmitting abilities were also predicted based on a cross-sectional model for lactation mean SCS. Only first-crop daughters were used in genetic evaluation of SCS, and the different selection criteria were compared based on their correlation with incidence of clinical mastitis in second-crop daughters (measured as mean daughter deviations). Selection criteria were predicted based on both complete and reduced first-crop daughter groups (261 or 65 daughters per sire, respectively). For complete daughter groups, predicted transmitting abilities at around $30 \mathrm{~d}$ in milk showed the best predictive ability for incidence of clinical mastitis, closely followed by average predicted transmitting abilities over the entire lactation. Both of these criteria were derived from the random regression model. These selection criteria improved accuracy of selection by approximately $2 \%$ relative to a cross-sectional model. However, for reduced daughter groups, the cross-sectional model yielded increased predictive ability compared with the selection criteria based on the random regression model. This result may be explained by the cross-sectional model being more robust, i.e., less sensitive to precision of (co)variance components estimates and effects of data structure.

(Key words: clinical mastitis, dairy cattle, random regression model, somatic cell score)

Abbreviation key: $\mathbf{C M}=$ clinical mastitis, $\mathbf{D D}=$ mean daughter deviation, LSCS = lactation mean SCS, $\mathbf{R R C}=$ random regression coefficient, $\mathbf{R R M}=$ random regression model.

Received October 11, 2004.

Accepted December 16, 2004.

Corresponding author: J. Ødegård; e-mail: jorgen.odegard@ umb.no.

\section{INTRODUCTION}

Selection for lower SCS is currently used to genetically improve mastitis resistance. When selection is based on cross-sectional or repeatability models, breeding values reflect the average genetic effects throughout the lactation. Compared with cross-sectional models, test-day models have the advantage of allowing for more precise adjustment for temporary environmental effects and for stage of lactation (Jensen, 2001). Therefore, test-day models are expected to yield more accurate genetic evaluations. In addition, as genetic correlations between SCS measured at different stages of lactation are less than unity (Reents et al., 1994; Mrode et al., 1998; Haile Mariam et al., 2001), modeling testday SCS as repeated measurements of the same trait (repeatability model) would probably be suboptimal. This weakness of the repeatability model has also been demonstrated by Ødegård et al. (2003a) in analysis of test-day SCS, who reported better fit, smaller residual variance, and improved predictive ability (of randomly excluded observations) for random regression models (RRM) than for a repeatability model.

Using an RRM, multiple random regression coefficients (RRC) are calculated per animal based on polynomials, which are functions of DIM. From the RRC, several different selection criteria can be calculated, such as PTA for specific DIM, weighted combinations of PTA at different DIM, and average PTA in a defined interval of lactation, or can be based on shape parameters for the trajectory of PTA by DIM. Currently, in some countries, EBV for SCS are calculated as the average of test-day EBV during the entire lactation (http:// www.interbull.slu.se).

The different selection criteria can be compared based on their ability to predict incidence of mastitis in future daughters. This ability can be estimated by correlating the various selection criteria, predicted from first-crop daughters, with mean daughter deviations (DD) for clinical mastitis (CM) in second-crop daughters (Ødegård et al., 2003c). The criterion with the highest correlation to DD for CM is expected to have the highest predictive ability, being proportional to accu- 
Table 1. Summary statistics of dataset of first-crop daughters with recorded test-day SCS.

\begin{tabular}{lcc}
\hline & $\begin{array}{c}\text { Complete daughter } \\
\text { groups }\end{array}$ & $\begin{array}{c}\text { Smaller daughter } \\
\text { groups }\end{array}$ \\
\hline Mean (SD) SCS & $4.11(1.19)$ & $4.10(1.19)$ \\
SCS test-day records, no. & $2,188,179$ & 548,564 \\
Cows, no. & 532,337 & 133,408 \\
Records per cow, mean no. (SD) & $4.11(1.35)$ & $4.11(1.35)$ \\
Sires, no. & 2043 & 2043 \\
Daughters per sire, mean no. (SD) & $261(55)$ & $65(16)$ \\
Herd-year classes, no. & 252,695 & 63,174 \\
\hline
\end{tabular}

racy of selection. Accuracy of selection also depends on data structure, with number of first-crop daughters per sire as the single most important factor. In Norway, the number of first-crop daughters per sire is large (averaging 261 in this data set). The accuracies of selection in cross-sectional and RRM may be affected differently by changes in data structure. Thus, the aim of this study was to compare various selection criteria for SCS, computed from RRM and a cross-sectional model, for large and small first-crop daughter groups.

\section{MATERIALS AND METHODS}

\section{Data}

Data were from a research database containing all phenotypic information from the Norwegian Dairy Herd Recording System from 1978 onward. A total of $2,188,179$ test-day SCC records from the first lactations of 532,337 first-crop daughters (Table 1) was extracted from a data set described by Ødegård et al. (2003b). Cows born $<6$ yr after their respective sires were defined as first-crop. Only daughters of the 2043 Norwegian Red sires progeny tested in the period from 1978 through 1995 were included. Records were restricted to those with SCC values between 5000 and 6,400,000 cells $/ \mathrm{mL}$ in the period from 6 to $305 \mathrm{DIM}$. The SCS was defined as the natural logarithm of $(\mathrm{SCC} / \mathrm{mL}) \times 10^{-3}$. In addition, a data set with reduced daughter group sizes was created by randomly excluding $75 \%$ of the herd-year classes from the complete data set. This data set had a total of 133,408 cows, corresponding to an average of 65 daughters per sire. Summary statistics for the 2 datasets are given in Table 1 .

Mastitis records were from a data set described by Heringstad et al. (2003). Daughters of Norwegian Red sires progeny tested in the period from 1978 to 1998 were included in the analyses. The data set had CM records for 1,599,566 cows with dates of first calving in the period from 1978 through 1999. The mastitis data set included both first- and second-crop daughters. Mastitis was defined as a binary trait based on whether the cow had at least one recorded veterinary treatment of
$\mathrm{CM}$ in the period from $15 \mathrm{~d}$ before calving to $305 \mathrm{~d}$ after calving (first lactation only). The overall mastitis frequency was $21 \%$.

In the analyses, PTA for SCS were based on the information that would be available at the time of selection. To avoid relatives such as granddaughters contributing to the PTA, sires were separated into 3 groups: sires born before September 14, 1979; sires born in the period from September 14, 1979 to August 31, 1985; and sires born after August 31, 1985. Accordingly, the daughters of these sires were split into 3 datasets, and transmitting abilities for each sire group were predicted from the corresponding and preceding data set(s).

The pedigree file used in genetic analysis of SCS was that described by Heringstad et al. (1999) and contained 2159 sires, of which 2043 had daughters with data. The pedigree file used in genetic analysis of CM contained 2726 sires, of which 2411 had daughters with data.

\section{Models}

Cross-sectional model for SCS. Lactation mean SCS (LSCS) was calculated as the arithmetic mean of test-day SCS for each cow and was analyzed with the following linear sire model (Ødegård et al., 2003b):

$$
\mathrm{Y}_{\mathrm{ijklm}}=\mathrm{A}_{\mathrm{i}}+\mathrm{M}_{\mathrm{j}}+\mathrm{HY}_{\mathrm{k}}+\mathrm{s}_{\mathrm{l}}+\mathrm{e}_{\mathrm{ijklm}}
$$

where

$$
\begin{aligned}
\mathrm{Y}_{\mathrm{ijklm}}= & \text { observation of LSCS for daughter } m \text { of sire } l, \\
& \text { calving at age } i \text {, in month } j, \text { and herd-year } \\
& \text { class } k \text {; } \\
\mathrm{A}_{\mathrm{i}}= & \text { fixed effect of age } i \text { at first calving, in } 15 \\
& \text { classes, where }<20 \text { mo is the first class, }>32 \\
& \text { mo is the last class, and the other classes are } \\
& \text { in single months; } \\
\mathrm{M}_{\mathrm{j}}= & \text { fixed effect of calendar month } j \text { of first calving, } \\
& \text { in } 12 \text { classes; } \\
\mathrm{HY}_{\mathrm{k}}= & \text { fixed effect of herd-year class } k ; \\
\mathrm{S}_{\mathrm{l}}= & \text { random effect of sire } l \text {; and } \\
\mathrm{e}_{\mathrm{ijklm}}= & \text { random error term. }
\end{aligned}
$$


The variance components estimated by Ødegård et al. (2003b) for the described model were used as input parameters in this analysis. The variances for sire and residual effects were 0.023 and 0.856 , respectively. The heritability of LSCS was 0.11 .

$\boldsymbol{R R M}$ for SCS. Based on test-day SCS, RRC for sires were predicted with the following linear model (Ødegård et al., 2003a):

$$
\begin{gathered}
\mathrm{Y}_{\mathrm{ijk} \text { mpq }}=\mathrm{A}_{\mathrm{i}}+\mathrm{M}_{\mathrm{j}}+\mathrm{HY}_{\mathrm{k}}+\mathrm{DIM}_{\mathrm{l}}+\mathrm{htd}_{\mathrm{m}} \\
+\sum_{\mathrm{n}=0}^{3} \mathrm{r}_{\mathrm{pn}} \mathrm{Z}(1)_{\mathrm{n}}+\sum_{\mathrm{n}=0}^{2} \mathrm{r}_{\mathrm{qn}} \mathrm{Z}(1)_{\mathrm{n}}+\mathrm{e}_{\mathrm{ijkl} \mathrm{mpq}}
\end{gathered}
$$

where

$\mathrm{Y}_{\mathrm{ijklmpq}}=$ observation of SCS for daughter $p$ of sire $q$, with age at calving $i$, calving month $j$, herdyear class $k$, DIM $l$, and herd test-day $m$;

$\mathrm{DIM}_{1}=$ fixed effect of DIM $l$, in 300 classes, where 6 $\mathrm{d}$ is the first class and $305 \mathrm{~d}$ is the last class;

$\mathrm{htd}_{\mathrm{m}}=$ random effect of herd test-day $m$;

$\mathrm{Z}(\mathrm{l})_{\mathrm{n}}=$ terms of a Legendre polynomial of order $n$ for DIM $l$, where $\mathrm{n}=\{0,1,2,3\}$ for permanent environmental effects and $n=\{0,1,2\}$ for sire effects;

$\mathrm{r}_{\mathrm{pn}}=$ random regression coefficient on $\mathrm{Z}(l)_{n}$ for the permanent environmental effect of cow $p$; and

$\mathrm{r}_{\mathrm{qn}}=$ random regression coefficient on $\mathrm{Z}(l)_{n}$ for the transmitting ability of sire $q$.

The other effects are as defined previously for LSCS. The variance components estimated by Ødegård et al. (2003a) for the described model were used as input parameters in this analysis. Heritabilities ranged from 0.07 to 0.10 .

Genetic analysis of CM. For CM, variance components and solutions for fixed and random effects were estimated with the following linear sire model (Heringstad et al., 1999):

$$
\mathrm{Y}_{\mathrm{ijklm}}=\mathrm{A}_{\mathrm{i}}+\mathrm{M}_{\mathrm{j}}+\mathrm{HY}_{\mathrm{k}}+\mathrm{s}_{\mathrm{l}}+\mathrm{e}_{\mathrm{ijklm}}
$$

where

$$
\begin{aligned}
\mathrm{Y}_{\mathrm{ijklm}}= & \text { observation of clinical mastitis }(0=\text { healthy, } \\
& 1=\text { diseased }) \text { for daughter } m \text { of sire } l \text {, calving } \\
& \text { at age } i \text {, in month } j, \text { and herd-year class } k \text { and } \\
& \text { fixed and random effects were as in the model } \\
& \text { for LSCS. }
\end{aligned}
$$

All genetic analyses were carried out using the DMU software package (Madsen and Jensen, 2000).

\section{DD for $\mathrm{CM}$}

The DD for CM were defined as the average per sire of mastitis observations for second-crop daughters deviated from solutions of fixed effects. A total of 931,873 second-crop daughters of the 382 sires that had $>300$ second-crop daughters were included in calculation of DD. Observations from herd-year classes with only a single record were discarded.

\section{Selection Criteria}

PTA from cross-sectional model. For a given sire $q$, the selection criteria from the cross-sectional model was PTA of LSCS $\left(P T A_{L S C S}\right)$.

PTA at specific DIM. For RRM, PTA for sire $q$ at a specific DIM $a$ was calculated using the following formula:

$$
\mathrm{PTA}_{a_{q}}=\sum_{n=0}^{2} r_{q n} Z(a) .
$$

PTA average for defined intervals of the lactation. The average PTA for a sire $q$ in an interval of the lactation from DIM $a$ to DIM $b$ was calculated as

$$
P T A_{a-b_{q}}=\frac{1}{b-a} \int_{a}^{b} \sum_{n=0}^{2} r_{q n} Z(1)_{n} d l .
$$

The following 4 sets of values were used for $a$ and $b$ : 1) 6 and 305 DIM, 2) 6 and 155 DIM, 3) 155 and 305 DIM, and 4) 105 and 205 DIM; generating 4 different selection criteria.

\section{Ranking of Selection Criteria}

Assuming the same selection intensity for all criteria, the correlation between selection criteria and secondcrop DD for CM can be used for ranking, as it is proportional to accuracy and, hence, to expected genetic response in the desired trait (CM) (Ødegård et al., 2003c). A weighted correlation was calculated for each criterion, using the number of second-crop daughters per sire as the weight.

\section{Direct Regression on RRC}

As the different selection criteria from the RRM all are linear combinations of the RRC, a weighted (by number of second-crop daughters per sire) multiple regression model was applied to estimate the linear combination of RRC that best fitted DD of CM. However, the corresponding multiple correlation was theoretically a measure of fit rather than a measure of predictive abil- 
Table 2. Weighted correlations $\left(\mathrm{r}_{\mathrm{DD}, \mathrm{SC}}\right)$ between second-crop mean daughter deviations (DD) for clinical mastitis and 8 selection criteria (SC) for 382 elite sires for data sets with complete and reduced daughter groups. Relative increases in accuracy of selection ${ }^{1}$ (RIAS) are also presented. Number of second-crop daughters per sire was used as weight.

\begin{tabular}{llcccc}
\hline & \multicolumn{2}{c}{$\begin{array}{c}\text { Complete daughter } \\
\text { groups }\end{array}$} & & \multicolumn{2}{c}{$\begin{array}{c}\text { Smaller daughter } \\
\text { groups }\end{array}$} \\
\cline { 2 - 3 } \cline { 5 - 6 } $\begin{array}{l}\text { Selection } \\
\text { criterion }\end{array}$ & $\mathrm{r}_{\mathrm{DD}, \mathrm{SC}}$ & $\begin{array}{l}\text { RIAS } \\
(\%)\end{array}$ & & $\mathrm{r}_{\mathrm{DD}, \mathrm{SC}}$ & $\begin{array}{c}\text { RIAS } \\
(\%)\end{array}$ \\
\hline $\mathrm{PTA}_{\mathrm{LSCS}}$ & 0.468 & 0.0 & & 0.411 & 0.0 \\
$\mathrm{PTA}_{6}$ & 0.471 & 0.6 & & 0.392 & -4.6 \\
$\mathrm{PTA}_{30}$ & 0.476 & 1.8 & & 0.402 & -2.2 \\
$\mathrm{PTA}_{305}$ & 0.406 & -13.2 & & 0.379 & -7.7 \\
$\mathrm{PTA}_{6}$ to 305 & 0.476 & 1.7 & & 0.403 & -1.9 \\
$\mathrm{PTA}_{6}$ to 155 & 0.470 & 0.4 & & 0.407 & -0.9 \\
$\mathrm{PTA}_{155}$ to 305 & 0.447 & -4.6 & & 0.408 & -0.7 \\
$\mathrm{PTA}_{105}$ to 205 & 0.471 & 0.7 & & 0.391 & -5.0 \\
\hline
\end{tabular}

${ }^{1}$ Percentage increase in accuracy of selection relative to the crosssectional model $\left(\mathrm{PTA}_{\mathrm{LSCS}}\right)$.

${ }^{2}$ PTA for lactation mean SCS (LSCS), specific DIM, or lactation intervals.

ity and should, therefore, be regarded primarily as an upper limit of predictive ability for a selection criterion derived from the RRM.

\section{RESULTS AND DISCUSSION}

The sire and residual variances from the genetic analysis of CM were 0.0013 and 0.1505 , respectively. The heritability estimate was 0.035 , which is in agreement with previously reported heritability estimates of CM from linear sire models (Heringstad et al., 2000).

The correlations between DD for CM and the different selection criteria are presented in Table 2 . For complete daughter groups, the correlations ranged between 0.41 and 0.48. Two criteria from the RRM, $\mathrm{PTA}_{305}$ and $\mathrm{PTA}_{155}$ to 305, showed lower correlations to DD than PTA from a cross-sectional model $\left(\mathrm{PTA}_{\mathrm{LSCS}}\right)$. Among all criteria, $\mathrm{PTA}_{30}$ had the highest correlation with $\mathrm{DD}$, closely followed by $\mathrm{PTA}_{6}$ to 305 . These criteria had correlations with DD that were from 1.7 to $1.8 \%$ higher than the correlation between DD and the cross-sectional model, and their predictive abilities were thus only slightly lower than the upper limit estimate of the multiple regression model (Table 3 ).

Figure 1 shows the correlation between DD and sires' PTA by DIM (6 to 305). The highest correlations were found approximately 1 mo after calving. Hence, selecting for lower SCS at this stage of lactation should have a preference. Furthermore, frequency of CM treatments was highest precisely at this stage of lactation. A plausible explanation for the results observed could be that the relationship between CM and SCS on the observable scale (direct relationship between a binary and
Table 3. Estimated weighted regression coefficients ( $\beta$ ), corresponding test statistic, and level of significance when regressing secondcrop mean daughter deviations (DD) for $\mathrm{CM}$ on random regression coefficients (RRC) of sires (382 elite sires) from a random regression model for test-day SCS records. Number of second-crop daughters per sire was used as weight. Data from complete daughter groups were used in the analysis.

\begin{tabular}{lcrr}
\hline & Estimate (SE) & \multicolumn{1}{l}{$F$} & \multicolumn{1}{l}{$P$} \\
\hline$\beta_{0}$ & $0.2020(0.0217)$ & 86.69 & $<0.0001$ \\
$\beta_{1}$ & $-0.0980(0.0584)$ & 2.32 & 0.0938 \\
$\beta_{2}$ & $0.4667(0.2028)$ & 5.30 & 0.0219 \\
$\mathrm{R}^{2}$ & 0.234 & & \\
Multiple correlation & 0.483 & & \\
\hline
\end{tabular}

continuous trait) influences the genetic covariance between the traits (Ødegård et al., 2004). If so, the maximum genetic covariance between the traits would be expected to coincide with the highest frequency of CM. However, this correlation also depends on accuracy of PTA.

For complete first-crop daughter groups, Pearson and Spearman rank correlations between the different selection criteria were similar and ranged from 0.7 to close to unity (Table 4). As expected, the lowest correlation was found between $\mathrm{PTA}_{6}$ and $\mathrm{PTA}_{305}$, which represent the extremes of the lactation. The highest correlation was found between $\mathrm{PTA}_{6}$ to 305 and $\mathrm{PTA}_{105}$ to 205, representing overlapping intervals.

The most striking result, however, was that the ranking of models was highly dependent on number of first-

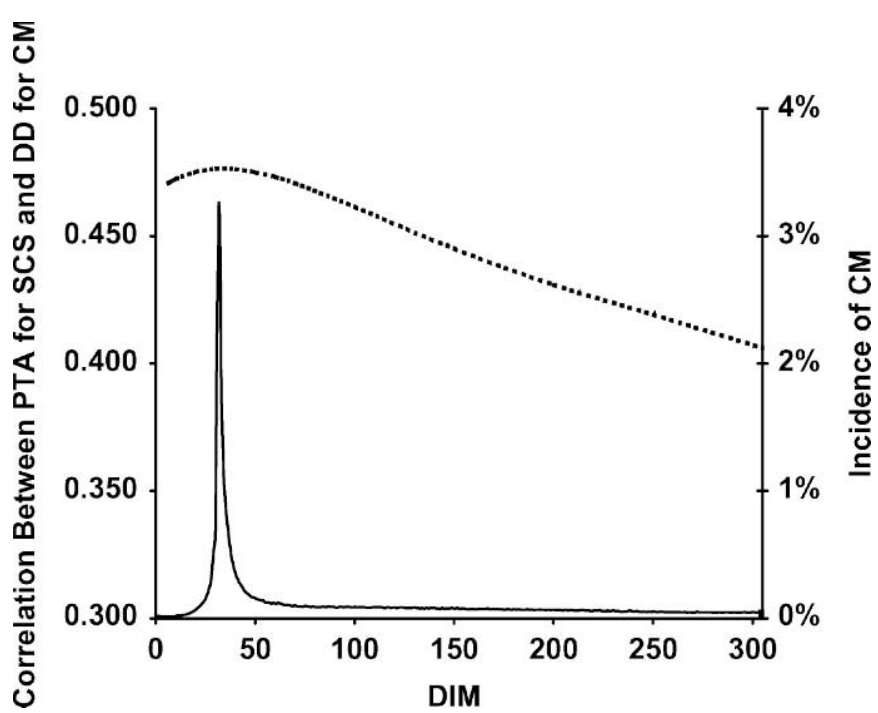

Figure 1. Trajectory for the correlation between PTA from random regression modeling of test-day SCS from first-crop daughters and second-crop mean daughter deviations for clinical mastitis (dotted line) by DIM and trajectory for daily incidence of veterinary treatments (including repeated treatments) for clinical mastitis (CM; solid line). $\mathrm{DD}=$ mean daughter deviation. 
Table 4. Pearson (above diagonal) and Spearman (below diagonal) correlations among the 8 selection criteria,${ }^{1}$ for 2043 sires with first-crop daughters. The PTA were predicted based on complete daughter groups.

\begin{tabular}{lllllllll}
\hline & $\mathrm{PTA}_{\text {LSCS }}$ & $\mathrm{PTA}_{6}$ & $\mathrm{PTA}_{30}$ & $\mathrm{PTA}_{305}$ & $\mathrm{PTA}_{6 \text { to } 305}$ & $\mathrm{PTA}_{6}$ to 155 & $\mathrm{PTA}_{155}$ to 305 & $\mathrm{PTA}_{105}$ to 205 \\
\hline PTA $_{\text {LSCS }}$ & & 0.911 & 0.953 & 0.924 & 0.978 & 0.988 & 0.902 & 0.988 \\
PTA $_{6}$ & 0.896 & & 0.992 & 0.723 & 0.930 & 0.947 & 0.848 & 0.918 \\
PTA $_{30}$ & 0.943 & 0.990 & & 0.796 & 0.959 & 0.981 & 0.869 & 0.955 \\
PTA $_{305}$ & 0.908 & 0.695 & 0.769 & & 0.921 & 0.887 & 0.903 & 0.938 \\
PTA $_{6 \text { to } 305}$ & 0.974 & 0.916 & 0.948 & 0.908 & & 0.977 & 0.964 & 0.997 \\
PTA $_{6}$ to 155 & 0.986 & 0.937 & 0.976 & 0.867 & 0.972 & & 0.884 & 0.985 \\
PTA $_{155}$ to 305 & 0.888 & 0.821 & 0.843 & 0.888 & 0.959 & 0.867 & & 0.947 \\
PTA $_{105}$ to 205 & 0.986 & 0.903 & 0.945 & 0.926 & 0.997 & 0.982 & 0.940 & \\
\hline
\end{tabular}

${ }^{1}$ PTA for lactation mean SCS (LSCS), specific DIM, or lactation intervals.

crop daughters per sire. When progeny group size was reduced from 261 to 65 daughters per sire, the PTA from the cross-sectional model were more highly correlated with DD for CM than was any selection criterion from the RRM (Table 2). Theoretically, the RRM should make better use of the information contained in the data. However, when using the RRM, the number of parameters in the model increases far more (e.g., one equation per sire cross-sectionally vs. 3 equations per sire and 4 equations per cow in RRM) than the number of data points ( 1 vs. 4 records per cow). Consequently, RRM are probably more likely to confound effects, which will affect the predictive ability of sire effects, but not necessarily the fit of the model, as considered by Ødegård et al. (2003a). Further, problems with confounding in complex models may, in turn, result in more imprecise estimates of (co)variance components, and this problem is often aggravated because of the computational limitations in (co)variance component estimation. Thus, by reducing number of first-crop daughters per sire, the effect of possibly inaccurate (co)variance estimates and confounding of random effects (such as sire and permanent environment) becomes more severe, especially for RRM. This explains the better performance of the cross-sectional model for this data structure. However, for data sets with more records per cow and larger herd-test-day groups, the RRM may be less sensitive to changes in size of first-crop daughter groups. Reducing daughter groups also led to some reranking of sires and less variability among the selection criteria derived from the RRM (Table 2), which may be explained by loss of accuracy caused by a reduced number of test-day records.

The recorded SCS is probably affected by unobserved cases of subclinical mastitis. Therefore, selection for reduced SCS is expected to have an effect on subclinical as well as CM. However, because of the lack of data for subclinical cases, ranking of the different selection criteria was solely based on recorded CM.

\section{CONCLUSIONS}

When large groups of first-crop daughters (261 daughters per sire) were available, the use of a RRM for genetic evaluation of SCS increased accuracy of selection by approximately $2 \%$, relative to a cross-sectional lactation model. Among the tested selection criteria, sire PTA 1 mo after calving $\left(\mathrm{PTA}_{30}\right)$ had the highest correlation with $\mathrm{CM}$ in future daughters, closely followed by average PTA throughout the entire lactation $\left(\mathrm{PTA}_{6}\right.$ to 305$)$. However, when daughter groups were smaller (65 daughters per sire), the PTA from the crosssectional model showed better predictive ability than did the selection criteria produced from the RRM. This result may be explained by the RRM being less robust with respect to precision of (co)variance component estimates and effects of data structure. Hence, RRM probably have the best prospects of improving accuracy of selection when considering well-structured data (e.g., large numbers of records per cow and daughters per sire).

\section{ACKNOWLEDGMENTS}

Access to the data was given by the Norwegian Dairy Herd Recording System in agreement number 6/1998 and 011/2000. GENO Breeding and A. I. Association is acknowledged for providing pedigree information on sires. The project has received funding from the Research Council of Norway and The Nordic Joint Committee for Agricultural Research (NKJ).

\section{REFERENCES}

Haile-Mariam, M., M. E. Goddard, and P. J. Bowman. 2001. Estimates of genetic parameters for daily somatic cell count of Australian dairy cattle. J. Dairy Sci. 84:1255-1264.

Heringstad, B., G. Klemetsdal, and J. Ruane. 1999. Clinical mastitis in Norwegian cattle: Frequency, variance components, and genetic correlation with protein yield. J. Dairy Sci. 82:1325-1330.

Heringstad, B., G. Klemetsdal, and J. Ruane. 2000. Selection for mastitis resistance in dairy cattle-A review with focus on the situation in the Nordic countries. Livest. Prod. Sci. 64:95-106. 
Heringstad, B., R. Rekaya, D. Gianola, G. Klemetsdal, and K. A. Weigel. 2003. Genetic change for clinical mastitis in Norwegian Cattle: A threshold model analysis. J. Dairy Sci. 86:369-375.

Jensen, J. 2001. Genetic evaluation of dairy cattle using test-day models. J. Dairy Sci. 84:2803-2812.

Madsen, P., and J. Jensen. 2000. A User's Guide to DMU. A Package for Analyzing Multivariate Mixed Models. Version 6, Release 4. Danish Institute of Agricultural Sciences, Research Centre Foulum, Tjele, Denmark.

Mrode, R. A., G. J. T. Swanson, and M. S. Winters. 1998. Genetic parameters and evaluations for somatic cell counts and its relationship with production and type traits in some dairy breeds in the United Kingdom. Anim. Sci. 66:569-576.

Ødegård, J., B. Heringstad, and G. Klemetsdal. 2004. Short communication: Bivariate genetic analysis of clinical mastitis and somatic cell count in Norwegian dairy cattle. J. Dairy Sci. 87:3515-3517.
Ødegård, J., J. Jensen, G. Klemetsdal, P. Madsen, and B. Heringstad. 2003a. Genetic analysis of somatic cell score in Norwegian cattle using random regression test-day models. J. Dairy Sci. $86: 4103-4114$

Ødegård, J., G. Klemetsdal, and B. Heringstad. 2003b. Variance components and genetic trend for somatic cell count in Norwegian cattle. Livest. Prod. Sci. 79:135-144.

Ødegård, J., G. Klemetsdal, and B. Heringstad. 2003c. Genetic improvement of mastitis resistance: Validation of somatic cell score and clinical mastitis as selection criteria. J. Dairy Sci. 86:4129-4136.

Reents, R., J. C. M. Dekkers, and L. R. Schaeffer. 1994. Genetic parameters of test-day somatic cell counts and production traits. Proc. 5th World Congr. Appl. Livest. Prod., Guelph, Ontario, Canada 17:120-123. 